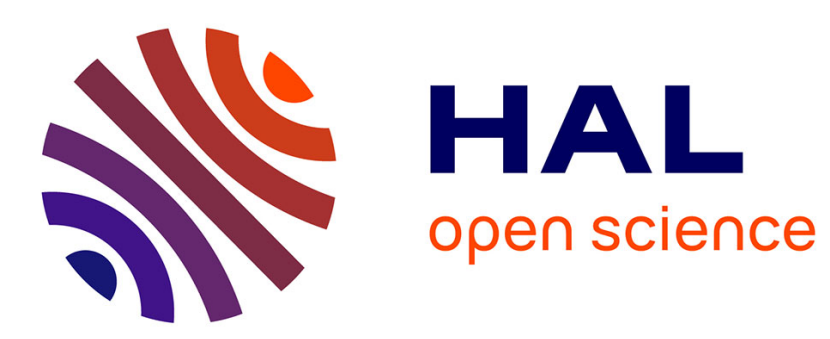

\title{
Modeling tree and grass dynamics: from demographic to spatially explicit models Jacques Gignoux, Sébastien Barot
}

\section{To cite this version:}

Jacques Gignoux, Sébastien Barot. Modeling tree and grass dynamics: from demographic to spatially explicit models. Luc Abbadie, Jacques Gignoux, Xavier Le Roux, Michel Lepage. 2007, Ecological studies 179. bioemco-00136603

\section{HAL Id: bioemco-00136603 https://hal-bioemco.ccsd.cnrs.fr/bioemco-00136603}

Submitted on 14 Mar 2007

HAL is a multi-disciplinary open access archive for the deposit and dissemination of scientific research documents, whether they are published or not. The documents may come from teaching and research institutions in France or abroad, or from public or private research centers.
L'archive ouverte pluridisciplinaire HAL, est destinée au dépôt et à la diffusion de documents scientifiques de niveau recherche, publiés ou non, émanant des établissements d'enseignement et de recherche français ou étrangers, des laboratoires publics ou privés. 


\section{Modeling Tree and Grass Dynamics: From Demographic to Spatially Explicit Models}

Jacques Gignoux and Sébastien Barot

\subsection{Introduction}

The question of the stability of Guinea savannas is still unresolved [23]: rainforests grow at the latitude of Lamto on similar soils. Fire is usually invoked to explain the stability of the forest-savanna boundary [20]. Without fire, trees are expected to outcompete grass. Because of the high production of the grass layer, the considerable fuel load present at the beginning of the long dry season results in the most severe surface fires observed on the West African climatic gradient. This would strongly limit tree recruitment, preventing their invasion in the area in spite of favorable climatic conditions.

This issue has been addressed in Lamto through experimental studies (Sect.18.4), the main one being the 40-year fire exclusion experiment (Fig. 18.3) and Vuattoux's long term succession study on plots subject to different fire treatments [34, 35, 11]. Results of this experiment (Sect. 18.5) demonstrate that fire excludes forest species, but does not prevent savanna tree species from invading except when fires occur late in the dry season (i.e., when trees have started shedding their leaves). The question of savanna stability is thus open for further investigation through modeling of the long term community dynamics.

Classical population dynamics studies have examined the persistence of grass [15] and tree [4] populations under current and experimental fire regimes. These studies enable one to assess whether particular species are able to maintain themselves or invade, but they do not point out the causes of specific success or failure to survive in a recurrently burned vegetation. More mechanistic approaches focusing on spatial pattern effects have been developed [21, 24, 19] in order to analyze the mechanism by which fire prevents tree invasion. This chapter presents these results and demonstrates how spatial pattern emerged as a determinant feature of savanna ecosystem dynamics. 


\subsection{Persistence of savanna species under annual burning: Analysis through matrix population models}

Two studies have focused on the demography of savanna species through classical methods (stage transition or Lefkovitch matrix models [7]) at Lamto: one examined the demography of one of the dominant grass species, Hyparrhenia diplandra, in relation to fire [15]; the other looked at the demography of the palm tree Borassus aethiopum, in order to determine whether the protected population of Lamto was stable in spite of the lack of formerly present animal dispersers [4].

\subsubsection{Effect of fire on grass demography and persistence}

Garnier followed for 3 years two populations of Hyparrhenia diplandra submitted to two fire treatments, yearly burned and unburned [15]. A total of 110 reproducing individuals plus 2867 dispersed seeds were tagged and followed during the experiment, enabling one to estimate the main demographic parameters of a 4 size-class stage-transition matric model. Two separate models, one for each treatment, were constructed (a fire survival parameter as included in the model for the burned treatment). Model analysis was performed with the ULM software [22, 13], which yields the population asymptotic growth rate (dominant eigenvalue of the transition matrix) and its sensitivity to parameters (e.g., sensitivities and elasticities).

Fire exclusion increased transition rates between size classes. From the analysis of the model, we have the following:

- The asymptotic growth rate was higher in the unburned plot than in the burned plot (1.23 instead of 1.07). Altering parameters to simulate a more severe fire resulted in a smaller value of 0.99 . In the unburned plot, simulating litter accumulation by reducing both germination and recruitment rates resulted in population growth rates close to that of the burned plot (1.08).

- The transition to the reproducing adult stage made the largest contribution to the population growth rate. In burned plots, the transition to the previous (non-reproducing adults) stage was almost as important.

- Sensitivity to the germination rate was higher in the unburned plot.

Annual burning has a strong effect on grass population, even if they seem well adapted to this environment (through a tussock life-form insulating buds from excessive heat and an hygrometric awn on seeds facilitating their burying into the soil [16]). Fire significantly reduces the population growth rate and affects life history traits. Similar studies conducted in other tropical savannas on Andropogoneae species [31, 32, 25] showed a different pattern, with a higher population growth rate in the burned treatment. This was interpreted as a negative effect of litter accumulation, not observed over the duration of the experiment in Lamto, but likely in the long term according to model results. 
Even an apparently well adapted, fire-prone species like the dominant grass species Hyparrhenia diplandra showed a positive response to fire exclusion. However, it is not clear whether the long term positive effect of fire exclusion on survival and recruitment balances the negative effect of litter accumulation. Hyparrhenia diplandra could well show no demographic response to fire exclusion in the long term (compare the 1.07 growth rate under the annual fire regime to the 1.08 value under fire exclusion + litter accumulation scenario), which is a clear disadvantage relative to trees: after 35 years of fire exclusion, grasses are outcompeted by trees through competition for light (Sect. 8.2).

\subsubsection{Tree persistence and reproductive strategy: The case study of Borassus aethiopum}

Barot designed a one-sex female based Lefkovitch matrix population model with five stages [4]: seeds, EL-seedlings, SL-seedlings, juveniles and adults (Sect. 18.4). For each stage, a probability of survival and a probability of recruitment were defined. Retrogression to a previous stage was allowed for non-reproductive stages. Parameter estimation was based on the census of four plots (two grass savanna and two shrub savanna plots), yearly censused between 1996 and 1998. An average sex ratio of 0.5 was used since there was no significant difference in sex ratio among plots. Fecundity and germination rate were estimated from specific studies (Barot, unpublished data). Matrix models were analyzed with the ULM software [22]. Estimations of ages of the different stages were computed using a method based on the implicit presence of age/time in stage-classified models [9]. Five model parameterizations were used, one for each savanna plot and an average model. No significant difference between demographic parameters according to year and plot was detected.

From the analysis of the model, we have the following:

- The average (averaged over all plots and years) asymptotic population growth rate was 1.009 with a standard deviation of 0.010 . Single-plot models yielded growth rates between 0.993 (s.d. 0.019) and 1.007 (s.d. 0.009). Assuming a Normal distribution, none of these rates would be significantly different from 1.

- The observed stable stage distribution was significantly different from the predicted stable stage distribution in all models. The high sensitivity of the stable stage distribution to the juvenile-to-adult recruitment rate and the uncertainty in the estimation of this parameter could explain this discrepancy.

- Elasticities and sensitivity analyses demonstrate that the most sensitive stage is the juvenile stage (Fig. 19.1).

- The total conditional life span of adults is 114.9 years (s.d. 176.0), with a surprisingly low remaining life span of 22.7 years (s.d. 103.7). Juveniles have the highest remaining life span (79.1 years, s.d. 248.0).

The population of Borassus aethiopum seems very close to equilibrium (growth rate not significantly different from 1 and no significant difference between 

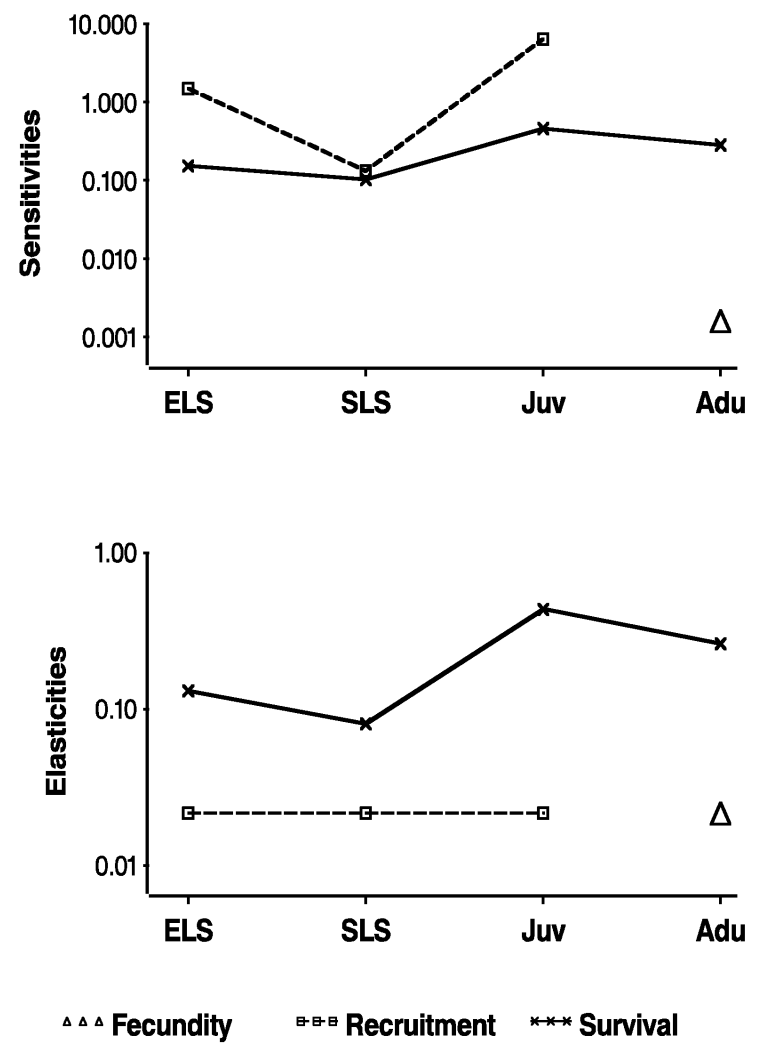

Fig. 19.1. Sensitivities and elasticities of the asymptotic growth rate to the matrix parameters for the Borassus population. Logarithmic scales were used as recommended in [6].

parameters across plots), although the stable stage distribution is not reached. This might be due to past disturbances (exceptionally fierce or late fires) or to the disparition in the Lamto area of seed dispersers (baboons and elephants), which would cause a change in demographic parameters. As previously suspected [1], Borassus aethiopum is very long lived, with a delayed reproduction and a short reproductive period, two unexpected features. Other studies of forest palm tree species show longer reproductive periods $([5,12,28,26,27]$ and Fig. 19.2).

Borassus aethiopum is able to persist in Lamto in the current conditions, and its population is very close to the demographic equilibrium. However, spatial pattern analyses (Sect. 18.3 and [1]) and analyses of seed dispersal [2] demonstrate that local variations of demographic parameters are significant in this species. We should therefore expect important changes in the demography 


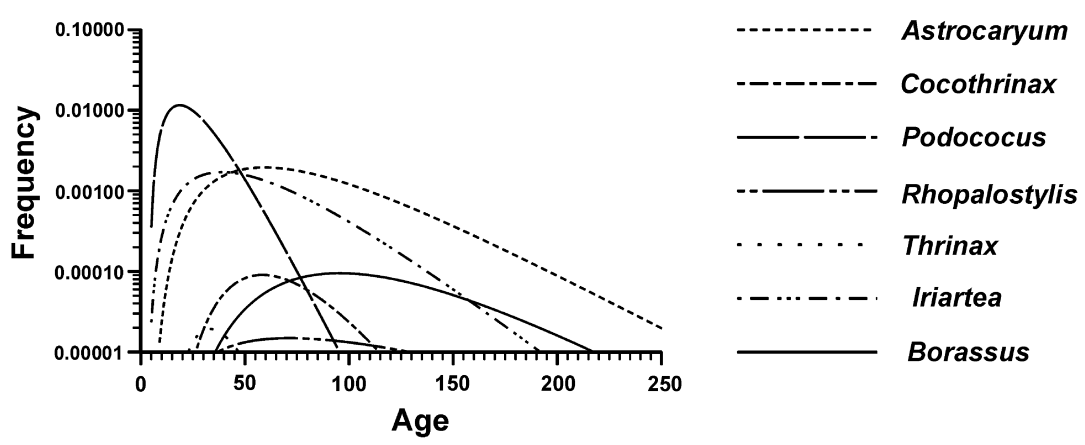

Fig. 19.2. Comparison of Borassus aethiopum stable age distribution estimated with matrix population models with other tropical forest palm tree species.

of Borassus aethiopum if those local parameters were to change, an hypothesis that the classical demographic approach used here is unable to test.

\subsubsection{Population persistence, fire, and demographic strategies of savanna plants}

The two previous modeling studies are the only attempts so far to look at the demography of the main plant species in Lamto through classical methods. We lack a larger sampling of species to really generalize these results, but two main facts arise form these studies.

First, the populations of two of the dominant species of Lamto are close to the demographic equilibrium, reinforcing the idea that fire is not a major problem for the persistence of these species in Guinea savannas. However, ambiguities remain and the matrix model approach used here does not allow a mechanistic analysis of the cause of this stability.

Second, the tree and grass species studied here have remarkably similar life spans: 120 years for the palm tree and 150 years for Hyparrhenia diplandra. These estimates are highly sensitive to the adult survival rates, which are difficult to estimate in short term studies. But even as order of magnitude, these estimates would look very similar. To generalize the conclusion of these studies, demographic analysis of the other dominant tree and grass species is required.

If dominant trees and grasses have similar life spans, can we find a reasonable selective pressure for this convergence, or is it due to pure chance? Given the competitive advantage of trees in the area, there should be a strong selective pressure on grass species to promote fire. This does not require them to be long lived (see, for example, the Northern Australian humid savannas, dominated by annual grasses [36]). Nutrient scarcity could select for this trait, since concentrating roots under grass tufts appears as an efficient way of recycling 
nitrogen (Sect. 15.5). Again, the comparison to North Australian savannas does not confirm this hypothesis, since nutrient levels are comparable in these annual-dominated savannas [10]). At this stage and without further studies on other species, there is no apparent reason for such a convergence in life spans.

\subsection{Spatialized demographic models}

Two articles have studied the effect of fire on tree spatial patterns and population dynamics through spatially explicit models, using very different formalisms [21, 24].

\subsubsection{The role of spatial pattern and fire in savanna dynamics}

The spatial pattern of the tree community in Lamto is complex (Sect. 18.3) and as for Borassus aethiopum, spatial variation in demographic parameters is expected $[2,3]$. This seriously limits the use of classical matrix population models for understanding the stability of this community.

Fire has a spatial component: the grass layer constitutes the fuel, and fuel load is reduced under tree clumps because of competition for light in favor of trees in these areas (Chap. 8). Different from most spatial effects examined in the literature (e.g., $[14,8]$ ), this effect is not due to preexisting environment heterogeneities, (like e.g., nutrient-rich patches due to soil heterogeneity independent of vegetation dynamics), but is generated by the dynamics of the tree populations, through their dispersal strategies and autogenerated spatial variations in recruitment rates. This led to the development of two spatial models of tree demography in relation to fire resistance.

\subsubsection{Continuous spatial model}

FRENCH $[17,24,19]$ is a simulation model developed to explore the causal mechanisms of vegetation structure in savanna communities. The principal aim is to analyze how a spatially explicit formulation can account for the role of fire in savannas and to what extent the individual performance of trees is responsible for the observed spatial pattern.

\section{Assumptions and model structure}

The model is based on three life history stages (seedlings, juveniles, and reproducing adults) and is characterized by the explicit treatment of the spatial structure of tree stands. Computations are thus performed at the individual level to study local interactions and neighborhood relationships [29, 30]. Trees, located by their coordinates on the map, are distributed in a continuous space with wrap-around margins to avoid edge effects [33]. 
Emphasis is given to the tree layer. Grasses are treated as a heterogeneous, tree- and fire-dependent pattern of constraints, which affects tree recruitment. The grass cover (spatial pattern of biomass) is a function of tree pattern and density, decreasing down to total disappearance under tree clumps comprising more than 6 individuals. Depending on rainfall, the grass cover can be irregularly burned (intensity and pattern of fire). This is modeled by attributing a variance to the mean value of tree seedling survival in the grass layer; survival values are then randomly computed within the range defined by this variance.

Species survival depends on the time-space constraints that affect the performance of individuals throughout their life cycle. Survival constraints are represented by two factors: fire and neighborhood competition functions. Resources are not explicitly treated. Species are characterized by seven parameters: reproductive output (expressed as seedlings), dispersal, reproductive lifetime, life span (age-specific survival process), individual growth rate, maximum diameter, and height. In the original version of the model, only one "synthetic" species was considered. The model has now been extended to enable many different tree species.

The inputs of the model, running on a yearly time step, are as follows:

- An initial distribution of trees (spatial pattern and size) over a $50 \times 50$ $\mathrm{m}$ savanna plot. It is based either on actual field data or on a random generator of plant distributions and positions (according to a random, regular or clumped spatial pattern).

- Four life history attributes: age-specific survival rate, reproductive lifetime, seedling production, and seedling dispersal.

- allometric relationships among tree basal diameter, height, and crown surface.

- Growth rules for seedlings, resprouts, and mature trees.

- Height of the grass cover and a function of grass biomass decrease in relation to tree density. Grass biomass is not introduced as such, but through its effects on tree growth and survival.

- Fire intensity, introduced as a function of grass biomass and fire regime: basically once a year, with the possibility to test different regimes (once every $n$ years, or total exclusion).

The outputs of the model are the following:

- a map of the plot with the positions and sizes of each individual, giving density and type of pattern; and

- the dimension and age of each individual, enabling calculation of the size and age class structure of the tree community.

All the details of the equations and parameters used in this model are presented in [24]. 


\section{Results}

Fire parameters appear to strongly determine the dynamics of the tree population [24]: in particular, with a homogeneous fire burning the whole surface, no recruitment of isolated trees (i.e., outside tree clumps) is possible; the intrinsic fire resistance of a tree species determines its ability to survive: low resistance species are quickly eliminated.

The fraction of the plot surface left unburned by chance is a key driver of tree dynamics [19] (Fig. 19.3): below a threshold surface left unburned (around $15 \%)$, trees go extinct; above this threshold and below a second one $(25 \%)$, the tree population stabilizes on average to typical densities of $200 \mathrm{ha}^{-1}$ observed
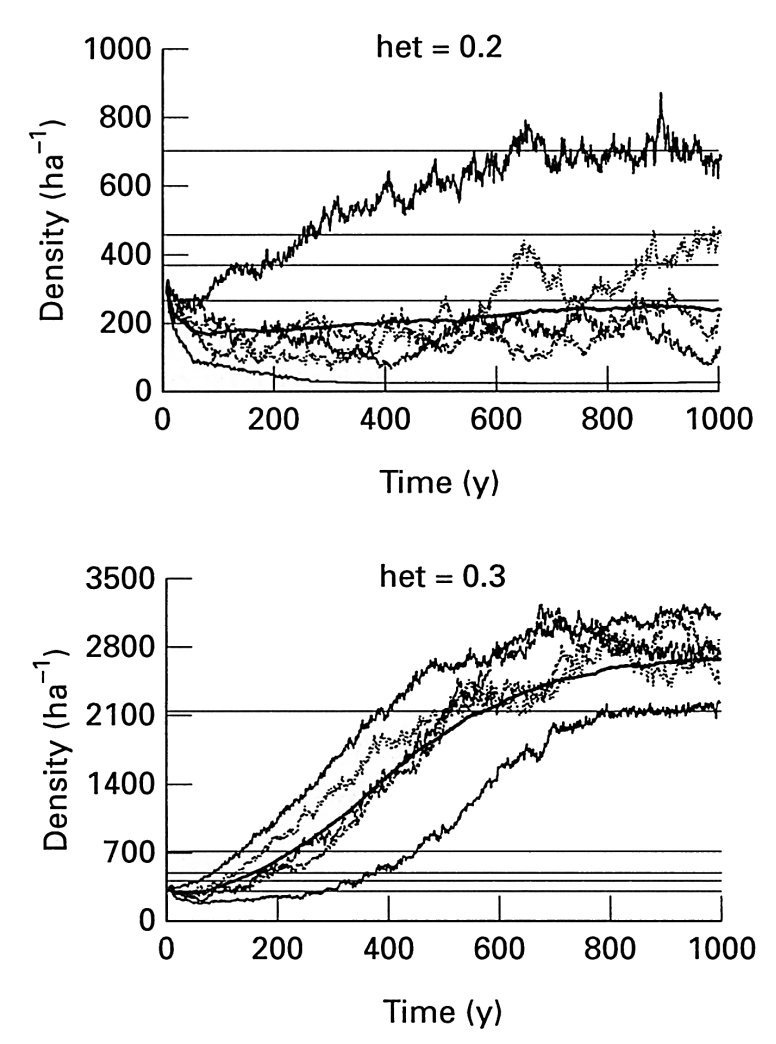

Fig. 19.3. Simulation of tree population dynamics with the FRENCH model. Parameter het measures the probability of escaping fire through pure chance for young tree. The system switches to fire-regulated, savanna-like (top), to competitionregulated, forest-like (bottom) for het between 0.2 and 0.3 . Solid line, average of 100 simulations; top and bottom lines, confidence interval (envelope of 100 simulations); horizontal lines, tree densities measured on real savanna plots for comparison (after [19], with permission of Blackwell Publishing). 
in the field; above the second threshold, the tree population stabilizes at large densities around $2500 \mathrm{ha}^{-1}$, only observed in the field in dense areas where grass has been excluded. This parameter thus separates a domain where tree existence is impossible from domains where the tree population is stabilized by fire or by intraspecific competition.

Spatial patterns generated through simulation were compatible with patterns observed in the field ( $97 \%$ of simulations had a clumped spatial pattern while all field plots exhibited such patterns).

\subsubsection{Cellular automaton model}

\section{Assumptions and model structure}

Hochberg et al. [21] used a minimally complicated algorithm to highlight the basic processes acting to determine spatial patterning in a single tree population. This approach corresponds closely to the category of cellular automaton models, where the habitat is broken up into a grid of spatially distinct, interacting cells. These cells can be either uninhabited or inhabited by a single dynamic entity such as an individual plant or a group of plants.

The system is modeled as a $n \times n$ grid of square cells, the whole grid being surrounded by grassland. The equations governing the changes in cell occupation by trees are iterated once per calendar year, and at the beginning of a given interaction, each cell can be in one of three states with respect to tree occupation: (i) unoccupied, (ii) occupied by reproductively immature trees, or (iii) occupied by mature trees. Demographic events can occur either purely within a cell (i.e., mortality not induced by fire), or in interaction with the eight immediately adjacent cells (i.e., mortality from fire, recruitment), or at longer distances (i.e., recruitment of dispersed seeds). The size of a given cell is $1 \mathrm{~m} \times 1 \mathrm{~m}$, which is approximately that permitting the growth of, at most, a single maximally reproductive individual. Intraspecific competition is not explicitly considered in the model; when cells are occupied by more than one reproductively mature individual, the largest is assumed to rapidly displace its competitors. Tree-tree competition between cells is of the pre-emptive type, such that the first individual arriving in a cell cannot be directly displaced by another. In our model, interspecific effects occur via fire, such that the (constant) grass population has a negative impact on tree seedlings. Thus, the absence of trees implies the presence of (fire conducting) grasses.

Details of the algorithm and parameter estimations can be found in [21].

\section{Results}

Model simulations predict that, in the presence of yearly fires, the doubling time of an initially randomly dispersed tree population is ca. 20-30 years. This estimation holds true until approximately $40 \%$ of the system is initially occupied by trees, beyond which (due to limits in the number of cells in the 
system) the doubling time rapidly approaches infinity. When mature trees are initially in the center of the system, the doubling time is substantially increased. In accordance with the doubling time of 30-40 years, the tree population reaches an equilibrium of ca. $90 \%$ cell occupancy by mature trees in 1200 years following the introduction of a single mature tree into the system. In the absence of fire, the doubling time decreases to about 6 years.

Clumping indices were computed to study the dynamics of the spatial pattern. They both show that fire reinforces tree aggregation: higher values of the clumpiness index are reached with fire, and clumpiness increases even when the initial population is random (Fig. 19.4).

\subsubsection{Fire and the stability of Guinea savannas as mixed life-form systems}

The models have complementary properties: while the FRENCH model enables one to compare simulated spatial patterns to field data, the cellular automaton model enables one to quantify aggregation in a more convenient way. Their results are remarkably similar in spite of an apparent contradiction: the FRENCH model demonstrates that fire can stabilize the tree population in certain conditions, but not the cellular automaton model (trees always invade, although more or less slowly). However, results of the FRENCH model show that the savannas of Lamto should be unstable at the landscape level. In this model, transition is possible from a fire-stabilized system to a

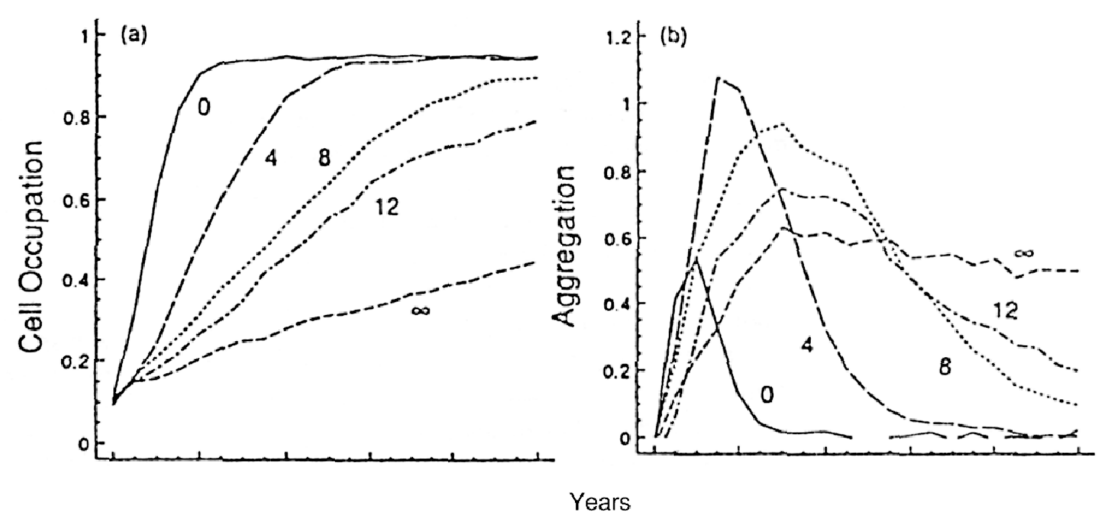

Fig. 19.4. Sensitivity of the cellular automata model to changes in burn threshold (number of encircling mature trees at or beyond which fire mortality is 0 ). (a) Fraction of cells occupied by mature trees. (b) Aggregation index as the number of couplings between mature trees divided by the expected number of couplings if trees were distributed randomly (from [21], with permission of Blackwell Publishing). 
competition stabilized system, but the reverse transition is impossible because grass has been eliminated in a competition-stabilized system. Therefore, if for any reason a tree clump appears and initiates a competition stabilized kernel, nothing will stop the slow invastion of trees from clump margins, exactly what the cellular automaton model predicts.

If invasion is not impossible, it is slow. The cellular automaton model predicts that, for a 0.25 ha plot as those studied in the field, competitionstabilized equilibrium should be reached in 1200 years in a burned system instead of 350 years in an unburned system (this prediction is made in the absence of long distance seed dispersal, i.e., only adjacent cells can be colonized by trees. These slow rates of invasion leave the possibility for rare catastrophic events-fierce fire, diseases, storms, exceptional droughts-to bring the tree population down to lower levels, ensuring long term stability of the tree-grass system.

Field results (Chap. 18) tend to confirm these conclusions since a significant increase in tree density has been observed in Lamto over 30 years. For example, the dynamics of the $\mathrm{G}$ and I plot between 1969 and 1989 (Fig. 18.4) is particularly interesting: in 1969, the two plots roughly had the same density; 20 years later, the I plot remains stable while a large tree clump has started to increase on the $\mathrm{G}$ plot, where grass is almost excluded. Only a slight difference in initial spatial pattern is visible on these plots.

Which factor should be invoked if fire does not stabilize the Guinea savannas in the long term? From the present knowledge, two hypotheses can be proposed:

- Different tree species have different fire resistances, and the interaction of such species could stabilize the tree community. A field experiment [18] demonstrated that fire resistance strategies were different among species and that a trade-off between resistance and competitive ability (individual growth rate) existed. This trade-off could probably lead to a 3-functional groups stable savanna: fire resistant trees would sometimes initiate clumps where they would be outcompeted by more fire sensitive trees; but because those trees recruit as a cohort of even aged trees, their synchronous death in a few years would lead to a collapse of their own population due to the coming back of grass and fire (Fig. 18.3). Field evidence supports the first part of this explanation, i.e., the invasion of dense tree clumps by less fire resistance species is common. But the collapse of such a population has never been recorded so far.

- Late fires, not represented in any of the two models, are able to kill adult trees (Sect. 18.2). They could be the rare, catastrophic events previously proposed: to reach stability, late fire (i.e., fires occurring at a sensitive phenological stage for trees) would have to occur from time to time. The continuous increase in tree density observed at Lamto and in the surrounding area could be due to the disparition of such late fires, either due to the planification of fire dates in the Lamto reserve or to the increase in human 
population outside the reserve (which statistically reduces the probability of an area reaching the end of the dry season without being burned).

The existing models can relatively easily be modified and parameterized to test these two hypotheses. If they remain inconclusive, other factors would have to be included to explain the stability of the Guinea savannas.

\subsection{Conclusion: The dynamics of plant populations and spatial patterns}

The major input of the works summarized here to the understanding of savannas is the evidence that population and community dynamics in mixed treegrass systems are closely linked to their spatial patterns and to the dynamics of these patterns. Static spatial pattern studies (Sects. 17.2 and 18.3) demonstrate a clear link between population dynamics and preexisting soil heterogeneities like the nutrient-rich patches constituted by old termite mounds. Classical demographic studies do not allow one to infer more than the ability of a population to stay in the system. Spatialized demographic modeling enables one to show the link between self-generated spatial patterns and long term plant dynamics: the long term unstability observed in the FRENCH model is due to the spatial patterns generated by fire; in a non-spatial model, the conclusion would probably have been that Guinea savannas were stable in the long term. These works were the impetus for further studies focusing on spatial issues in Lamto, like studies on mechanisms of dispersal and distance-dependent mortality and recruitment of seedlings [2].

\section{References}

1. S. Barot, J. Gignoux, and J.C. Menaut. Demography of a savanna palm tree: Predictions from comprehensive spatial pattern analyses. Ecology, 80(6):19872005, 1999.

2. S. Barot, J. Gignoux, and J.C. Menaut. Seed shadows, survival and recruitment: How simple mechanisms lead to the dynamics of population recruitment curves. Oikos, 86:320-330, 1999.

3. S. Barot, J. Gignoux, and J.C. Menaut. Neighborhood analysis in a savanna palm: Interplay of intraspecific competition and soil patchiness. Journal of Vegetation Science, 14:79-88, 2000.

4. S. Barot, J. Gignoux, R. Vuattoux, and S. Legendre. Demography of a savanna palm tree in Ivory coast (Lamto): Population persistence and life history. Journal of Tropical Ecology, 16:637-655, 2000.

5. S.H. Bullock. Demography of an undergrowth palm in littoral Cameroon. Biotropica, 12(4):247-255, 1980.

6. H. Caswell. Life cycle models for plants. Lectures on Mathematics in the Life Sciences, 18:171-233, 1986. 
7. H. Caswell. Matrix population models. Sinauer, Sunderland, MA, 1989.

8. P.L. Chesson. Coexistence of competitors in spatially and temporally varying environments: A look at the combined effects of different sorts of variability. Theoretical Population Biology, 28(3):263-287, 1984.

9. M.E. Cochran and S. Ellner. Simple methods for calculating age-based life history parameters for stage-structured populations. Ecological Monographs, 62(3):345-364, 1992.

10. G.D. Cook and M.H. Andrew. The nutrient capital of indigenous Sorghum species and other understorey components of savannas in North-Western Australia. Australian Journal of Ecology, 16:375-384, 1991.

11. J.L. Devineau, C. Lecordier, and R. Vuattoux. Evolution de la diversité spécifique du peuplement ligneux dans une succession préforestière de colonisation d'une savane protégée des feux (Lamto, Côte d'Ivoire). Candollea, 39:103134,1984

12. N.J. Enright and A.D. Watson. Population dynamics of the Nikau palm, Rhopalostylis sapida (Wendl. et Drude), in a temperate forest remnant near Auckland, New Zealand. New Zealand Journal of Botany, 30:29-43, 1992.

13. R. Ferrière, F. Sarrazin, S. Legendre, and J.P. Baron. Matrix population models applied to viability analysis and conservation: Theory and practice using ULM software. Acta Oecologica, 17:629-656, 1996.

14. R.H. Gardner and R.V. O'neill. Pattern, process and predictability: The use of neutral models for landscape analysis. In M.G. Turner and H. Gardner, editors, Quantitative methods in landscape ecology, volume 82 of Ecological studies, pages 289-307. Springer-Verlag, Berlin, 1991.

15. L.K. Garnier and I. Dajoz. The influence of fire on the demography of a dominant grass species of West African savannas, Hyparrhenia diplandra. Journal of Ecology, 89:200-208, 2001.

16. L.K.M. Garnier and I. Dajoz. Evolutionary significance of diaspore polymorphism in a clonal grass of fire prone savannas. Ecology, 82:1720-1733, 2001.

17. J. Gignoux. Modélisation de la dynamique d'une population ligneuse - Application à l'étude d'une savane africaine. M.Sc. thesis, Institut National Agronomique Paris-Grignon, Paris, 1988.

18. J. Gignoux, J. Clobert, and J.C. Menaut. Alternative fire resistance strategies in savanna trees. Oecologia, 110(4):576-583, 1997.

19. J. Gignoux, J.C. Menaut, I.R. Noble, and I.D. Davies. A spatial model of savanna function and dynamics: model description and preliminary results. In D.M. Newbery, H.H.T. Prins, and N.D. Brown, editors, Dynamics of tropical communities, volume 37 of Annual symposium of the BES, pages 361-383. Blackwell Scientific Publications, Cambridge, 1998.

20. D. Gillon. The fire problem in tropical savannas. In F. Bourlière, editor, Tropical savannas, volume 13 of Ecosystems of the world, pages 617-642. Elsevier, Amsterdam, 1983.

21. M.E. Hochberg, J.C. Menaut, and J. Gignoux. The influences of tree biology and fire in the spatial structure of the West African savanna. Journal of Ecology, 82(2):217-226, 1994.

22. S. Legendre and J. Clobert. ULM, a software for conservation and evolutionary biologists. Journal of Applied Statistics, 22:817-834, 1995.

23. J.C. Menaut. The vegetation of african savannas. In F. Bourlière, editor, Tropical Savannas, volume 13, pages 109-149. Elsevier, 1983. 
24. J.C. Menaut, J. Gignoux, C. Prado, and J. Clobert. Tree community dynamics in a humid savanna of the Côte d'Ivoire: Modelling the effects of fire and competition with grass and neighbours. Journal of Biogeography, 17:471-481, 1990.

25. J.J. Mott and A.J. McComb. Patterns in annual vegetation and soil microrelief in an arid region of Western Australia. Journal of Ecology, 62:115-125, 1974.

26. I. Olmsted and E.R. Alvarez-Buylla. Sustainable harvesting of tropical trees: Demography and matrix models of two palm species in Mexico. Ecological Applications, 5(2):484-500, 1995.

27. M. Piñard. Impacts of stem harvesting on populations of Iriartea deltoidea (Palmae) in extractive reserve in Acre, Brazil. Biotropica, 25:2-14, 1993.

28. D. Piñero, M. Martínez-Ramos, and J. Sarukhán. A population model of Astrocaryum mexicanum and a sensitivity analysis of its finite rate of increase. Journal of Ecology, 72:977-991, 1984.

29. C. Prado. Un modèle de succession végétale: Rôle des traits biologiques des espèces et des contraintes spatiales. Ph.D. thesis, Université de Paris 6, Paris, 1988.

30. C. Prado. Plant community dynamics and species growth rules: A simulation study based on a cellular automata formalism. In A. Pavé and G.C. Vansteekiste, editors, Artificial intelligence in numerical and symbolic simulation, pages 7587. ALEAS, Paris, 1991.

31. J.F. Silva, J. Raventos, and H. Caswell. Fire and fire exclusion effects on the growth and survival of two savanna grasses. Acta Oecologica, 11(6):783-800, 1990.

32. J.F. Silva, J. Raventos, H. Caswell, and M.C. Trevisan. Population responses to fire in a tropical savanna grass, Andropogon semiberbis - a matrix model approach. Journal of Ecology, 79(2):345-356, 1991.

33. O. Van Tongeren and I.C. Prentice. A spatial simulation model for vegetation dynamics. Vegetatio, 65:163-173, 1986.

34. R. Vuattoux. Observations sur l'évolution des strates arborée et arbustive dans la savane de Lamto (Côte d'Ivoire). Annales de l'Université d'Abidjan, Série E, $3(1): 285-315,1970$.

35. R. Vuattoux. Contribution à l'étude de l'évolution des strates arborée et arbustive dans la savane de Lamto (Côte d'Ivoire). Deuxième note. Annales de l'Université d'Abidjan, Série C, 7(1):35-63, 1976.

36. A.R. Watkinson, W.M. Lonsdale, and M.H. Andrew. Modelling the population dynamics of an annual plant sorghum intrans in the wet-dry tropics. Journal of Ecology, 77:162-181, 1989. 